\title{
Control of antral follicle development and selection in sheep and cattle
}

\author{
B. K. Campbell ${ }^{1}$, R. J. Scaramuzzi ${ }^{2}$ and R. Webb ${ }^{1}$ \\ ${ }^{1}$ Roslin Institute, Roslin, Midlothian, EH25 9PS, UK; and ${ }^{2}$ The Royal Veterinary College, \\ University of London, Royal College Street, London, NW1 OTU, UK
}

\begin{abstract}
The development of antral follicles in sheep and cattle is dependent on FSH, but large antral follicles can shift their gonadotrophic dependence from FSH to LH. The mechanisms that result in the selection of at least one ovulatory follicle from identical follicular cohorts, exposed to the same endocrine environment, still remain to be elucidated. The aim of this research was to extend in vitro results from the rodent to sheep and cattle and, using both in vivo and in vitro models, to identify factors that can enhance or attenuate the action of gonadotrophins in stimulating follicle development. Using sheep with ovarian autotransplants, we have obtained evidence to show that a number of factors inhibit ovarian function in vivo, whereas only insulin-like growth factor I (IGF-I) has a stimulatory effect. Further study of the mechanism of action of these factors at a cellular level has been made possible by the development of a serum-free granulosa cell culture system for both sheep and cattle that allows induction and maintenance of oestradiol production. Using this model system, we have confirmed many of the results from our studies in vivo and have shown that IGF-I and insulin interact at physiological concentrations to influence both cellular proliferation and oestradiol production. Overall, these data support the hypothesis that the physiological basis of follicle selection is the differential expression of factors that modulate the action of gonadotrophins on follicular cells at key points during the process of follicle development.
\end{abstract}

\section{Introduction}

An intriguing conceptual problem in the study of reproductive biology of domestic ruminants is the mechanism of follicle selection. Despite the presence of a large number of preantral (12 000-86 000) and antral (50-400) follicles (Turnbull et al., 1977; Rajakoski, 1960), the number of follicles that ovulate at each oestrous cycle is precisely controlled and exhibits little variation. This is particularly true in cattle which are mainly monovular ( $>95 \%$ ), whereas in sheep ovulation rate is breed specific and ovulation rates can vary between breeds from 1.1 in the Australian Merino to greater than 3 in breeds such as the Finnish Landrace and Romanov. In addition, specific genes such as FecB (McNatty et al, 1987) have been identified in sheep that result in ovulation rates greater than 5 .

The ovulation rate of a particular animal is therefore determined by its genotype and can be constrained by environmental factors such as nutrition and photoperiod. The phenotypic expression of ovulation rate is determined by a physiological mechanism that integrates environmental inputs within a genetically pre-determined range. The ability to manipulate ovulation rate in large domestic ruminants has commercial significance as a means of controlling reproductive performance. Reproductive performance is determined as the product of three factors: prolificacy, fertility and postnatal survival. Prolificacy is a major determinant of reproductive performance and in sheep is determined to a large extent by ovulation rate. Fertility is also influenced, although to a lesser extent, by ovulation rate. 
Consequently, the study of mechanisms that determine ovulation rate and their interactions with environmental and genetic factors has been an important objective of reproductive research. Ovulation rate is determined by the mechanisms that control selection of the ovulatory follicle from among follicular cohorts. Here we review the results of our most recent studies on the endocrine and intraovarian control of antral follicle development and selection in sheep and cattle.

\section{Folliculogenesis in Sheep and Cattle}

Folliculogenesis is controlled by complex relationships between the intrafollicular steroids, growth factors, extraovarian factors and the hypothalamo-pituitary-ovarian feedback system. Follicle growth is a process during which the follicle progressively acquires a number of properties, each of which is an essential prerequisite for further development. Failure to acquire these properties at the correct time and in an exact sequence will lead to failure of the process and to the deterioration of the follicle through atresia. Accordingly, the follicle classification system proposed by Scaramuzzi et al. (1993) that is based on physiological rather than morphological criteria will be used in this review.

The pattern of follicle development in sheep and cattle is generally similar and differences tend to be morphological rather than physiological (Turnbull et al., 1977; Lussier et al., 1987). There are, however, physiological differences between these species and these will be discussed in later sections. In contrast to rodents, folliculogenesis in sheep and cattle is a lengthy process as it takes about I80 days for a follicle to grow from its primordial state $(100 \mu \mathrm{m})$ to ovulatory (sheep $>5 \mathrm{~mm}$; cattle $>10 \mathrm{~mm}$ ) size (Cahill and Mauleon, 1981). Antrum formation occurs at a follicular diameter (fixed ovaries) of $0.2-0.4 \mathrm{~mm}$ in sheep and $0.4-0.8 \mathrm{~mm}$ in cattle and it takes a further 40 days for follicles to reach ovulatory size (Turnbull et al., 1977; Lussier et al., 1987). The most striking feature of follicular development in both sheep and cattle is the presence of a marked hierarchy in the antral follicle population with a large number (20-30) of gonadotrophin-responsive follicles (sheep 2-3 mm; cattle 3-4 mm), a few ( $1-4)$ gonadotrophin-dependent follicles (sheep $>3.5 \mathrm{~mm}$; caltle $>4-5 \mathrm{~mm}$ ) and the number of ovulatory follicles that is characteristic of the ovulation rate of that breed (sheep 1-4; cattle 1). An ovulatory follicle is a large ( $>4 \mathrm{~mm}$ sheep; $>8 \mathrm{~mm}$ cattle), highly vascularized follicle which is oestrogenic and has a full complement of granulosa cells containing LH receptors (Webb and England, 1982; Ireland and Roche, 1983). Although capable of ovulation (Price and Webb, 1989; Driancourt et al., 1988), the ovulatory follicle will only do so if it can induce an ovulatory LH surge. If not, the ovulatory follicle will become atretic and another follicle recruited from the gonadotrophin-responsive pool will develop to replace it. In contrast to other monovulatory animals such as primates, in large domestic ruminants this cycle of follicle growth and development is independent of the oestrous cycle. That is, it takes place regardless of the presence of oestrous cycles so that the average number of ovulatory follicles, present on the ovaries at any time, appears to be constant, regardless of physiological state, and is approximately equal to the average ovulation rate (Ireland and Roche, 1983; Webb and Gauld, 1985). In cattle, the advent of ultrasound scanning has confirmed earlier histological (Rajakoski, 1960) reports that development of large follicles occurs as a series of waves during the luteal phase with a period of 7-10 days (Sirois and Fortune, 1988). In sheep, although the presence of luteal phase FSH waves with a period of 4-5 days (Campbell et al. 1991a) has provided indirect evidence of similar waves of follide development, direct evidence, based on functional rather than anatomical (Schrick et al., 1993) identification of ovulatory follicles, is still lacking.

In animals exhibiting oestrous cycles, these regular waves of ovulatory follicle development are interrupted by the process of ovulation. Within $10-12 \mathrm{~h}$ of luteal regression a preovulatory follicle(s), which is derived from either gonadotrophic-dependent or ovulatory follicles, emerges and under the influence of increased LH stimulation this follicle(s) will secrete sufficient oestradiol to induce the preovulatory LH surge within $48-60 \mathrm{~h}$ (Baird and McNeilly, 1981). The endocrine changes that occur during this follicular phase result in removal, through ovulation or atresia, of the antral follicle hierarchy, such that follicle development is re-initiated in the period after ovulation from the recruitable pool of gonadotrophin-responsive follicles in response to the peak of FSH concentrations on day I (Campbell et al., 1990). 


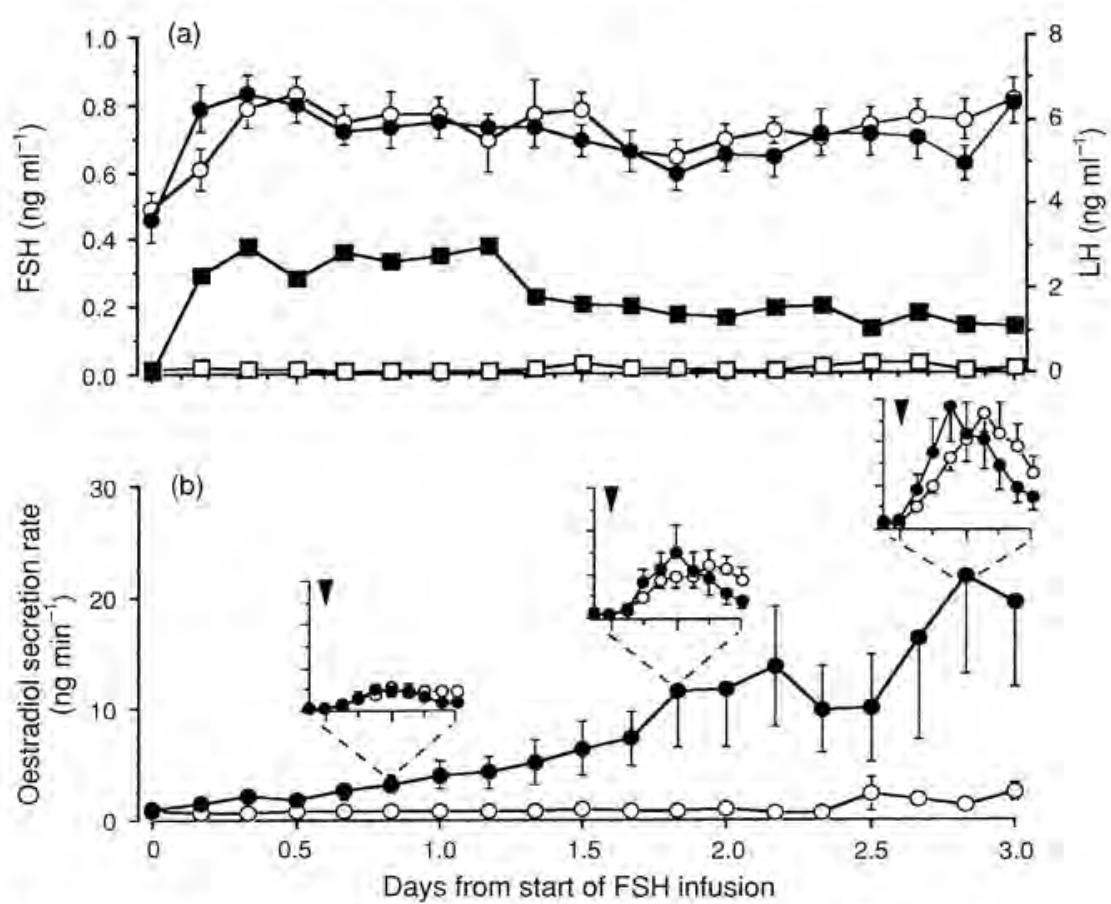

Fig. 1. The effect of continuous infusion of oFSH-S16 $\left(5 \mu \mathrm{g} \mathrm{h}^{-1}\right)$ of ewes with ovarian autotransplants (treated with a potent GnRH antagonist to suppress endogenous gonadotrophins) that received no $\mathrm{LH}(n=9 ; 0, \bar{D})$ or $\mathrm{LH}(2.5 \mu \mathrm{g}$ oLH-S26) every $4 \mathrm{~h}(n=9 ; \bullet$, -) on (a) peripheral FSH $(0,-)$ and $\mathrm{LH}$ concentrations $(\mathbf{m}, \square)$ and (b) ovarian oestradiol secretion rates. (b) Oestradiol secretion determined from samples of ovarian blood taken every $4 \mathrm{~h}$; the inserts show the secretory response to a single test pulse of $\mathrm{LH}(2.5 \mu \mathrm{g}$ oLH-S26) in both groups. Despite differences in endogenous secretion in the two groups owing to the lack of $\mathrm{LH}$ stimulation, the presence or absence of low amplitude LH pulses (3-4 $\mathrm{ng} \mathrm{ml}^{-1}$ ) had no effect on FSH-stimulated follicle development as illustrated by the lack of difference in the oestrogenic response to LH stimulation. (Reproduced from Campbell et al.. 1993a.)

\section{Gonadotrophins and follicle selection}

Antral follicles larger than $3 \mathrm{~mm}$ in sheep (McNeilly et al., 1991) and $4 \mathrm{~mm}$ in cattle (J. G. Gong, personal communication) are termed gonadotrophin-dependent, as these follicles are not observed in the ovaries of animals in which endogenous gonadotrophin concentrations are suppressed by removal or inhibition of GnRH action. Studies, using a sheep model based on a potent GnRH agonist to suppress endogenous gonadotrophins in conjunction with hormone replacement therapy, have shown that the growth of follicles to an ovulatory size is totally dependent on FSH and that the number of follicles that develop is dependent on both the amount of FSH and the time of exposure to FSH (Picton et al., 1990). Although LH alone will not stimulate follicular development, high amplitude LH pulses can partially inhibit the stimulatory action of FSH on follicular growth, depending on the level of FSH stimulation (McNeilly et al., 1991). Furthermore, complete removal of LH by passive immunization inhibits FSH-stimulated follicular development (McNeilly et al., 1991). Using a similar model in conjunction with the ovarian autotransplant model (Baird and McNeilly, 1981), we have confirmed and extended these results to show that LH pulses of low amplitude and frequency have litfle effect on the ability of FSH to stimulate the development of large antral follicles (Fig. I) and, in the absence of LH, these follicles remain critically dependent on FSH for gonadotrophic support (Fig. 2a). However, large antral follicles can transfer their gonadotrophic requirements from FSH to LH if it is delivered as high frequency, low 
amplitude pulses (Fig. 2b). Having transferred their gonadotrophic requirement from FSH to LH, these follicles become critically dependent on LH for support and cessation of high frequency LH pulses will lead to rapid atresia characterized by cessation of the ability of the follicles to respond to single stimulatory pulses of LH (Fig. 3). This transference of gonadotrophic requirement from FSH to $\mathrm{LH}$ is the probable mechanism whereby the preovulatory follicle can withstand the fall in FSH that occurs at the onset of the follicular phase following luteal regression.

These studies also give us insights into the ovulatory follicles that develop during the luteal phase or periods of anoestrus. In contrast to preovulatory follicles, which develop during the follicular phase
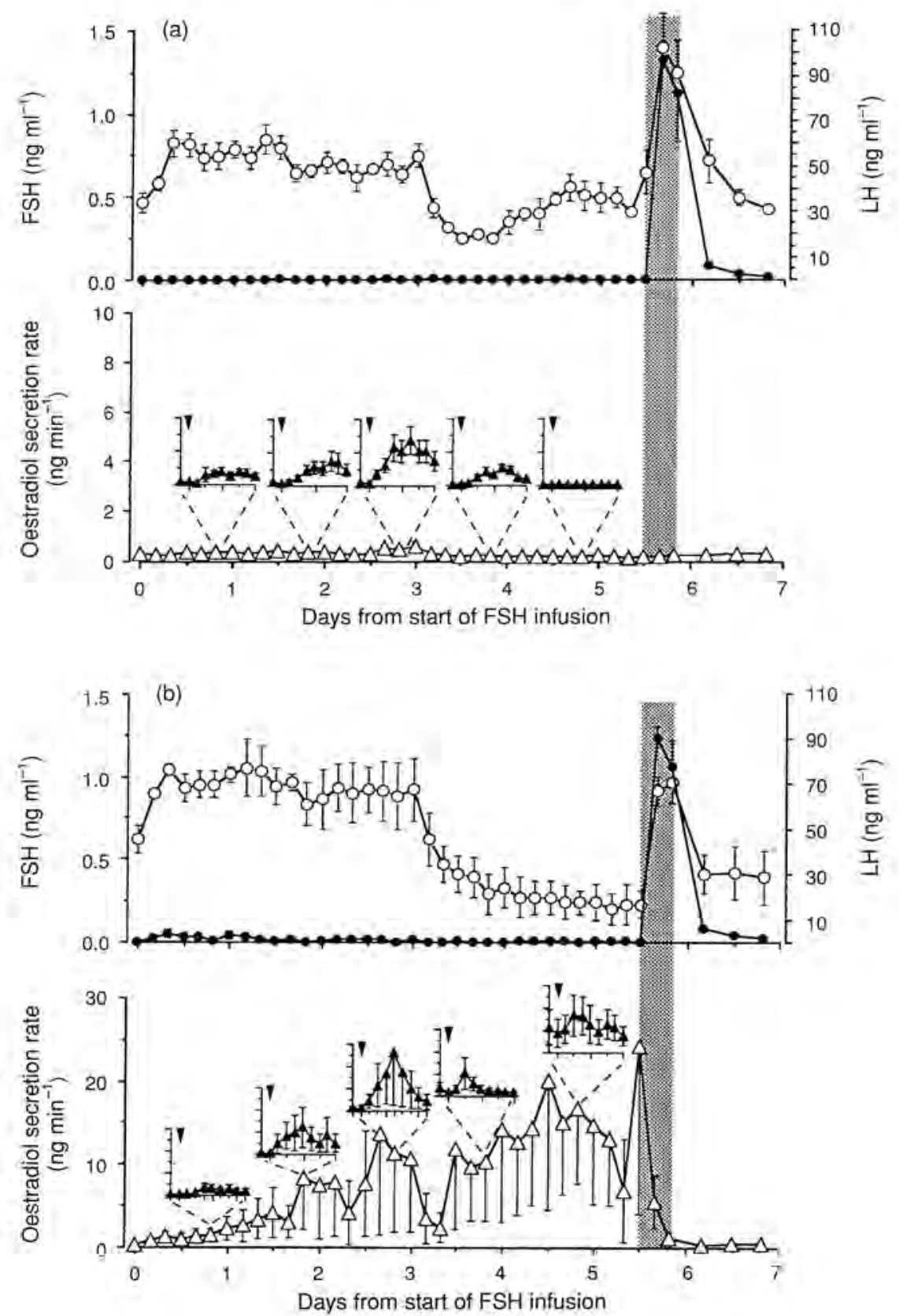
under conditions of reducing FSH and increasing $\mathrm{LH}$, these ovulatory follicles develop under conditions of high FSH and low LH pulse frequency. Under these conditions, in which progesterone or increases in pituitary sensitivity to oestradiol prevents an increase in $\mathrm{LH}$ pulse frequency, the lifespan of the ovulatory follicle is probably limited by its failure to withstand the fall in FSH caused by the oestradiol and inhibin it is itself secreting (Campbell et al., 1990). Recent evidence from cattle showing that the life of the ovulatory follicle can be prolonged by increasing LH pulse frequency during the luteal phase supports this view (Savio et al., 1993).

Owing to the key role that FSH plays in the control of development of ovulatory follicles, it is widely assumed that FSH plays a key role in the determination of ovulation rate. This contention is supported by strong evidence obtained over many years showing that treatment with exogenous FSH (McNatty et al., 1985) or gonadotrophins with FSH-like activity (Monniaux ef al., 1983), or treatments that lead to increases in endogenous FSH concentrations (Wallace and McNeilly, 1985), all increase ovulation rate. These observations have stimulated a search for correlations between physiological concentrations of FSH and ovulation rate in sheep with genetically or environmentally induced variation in ovulation rate. This search has been unrewarding (Webb and England, 1982; Scaramuzzi and Radford, 1983; Driancourt et al., 1988; Campbell et al, 1991a) with some possible exceptions (Lahlou-Kassi et al., 1984; McNatty ef al, 1987). The most obvious explanation for the failure to demonstrate this relationship is that multiple follicular development leads to increased ovarian secretion of oestradiol or inhibin that lowers the concentration of FSH. Two of the few cases where peripheral concentrations of FSH are increased in conjunction with increased follicular development and ovulation rate occurs when the normal feedback relationships are circumvented by immunization against oestradiol (Scaramuzzi, 1976) or inhibin (Findlay et al., 1990; Glencross et al, 1992). Although FSH plays a critical role in the stimulation of follicular growth, and large increases in FSH concentrations increase ovulation rate, in normal cyclic animals, differences between animals in the concentration of FSH in jugular venous plasma have little bearing on ovulatory potential. However, the variation in FSH concentrations within animals throughout the oestrous cycle appears to play a critical role in follicle selection as the ovulatory follicle may suppress the growth of cohorts by controlling peripheral FSH concentrations.

From the discussion above it is clear that follicles depend on FSH for their growth and development beyond $2-4 \mathrm{~mm}$ in diameter and that blood concentrations of FSH do not determine ovulation rate in normal physiological states. However, the mechanism that allows at least one follicle to develop whereas seemingly identical follicular cohorts exposed to the same endocrine environment become atretic is not known. As it is obvious that different follicles within the ovary are differentially sensitive to the action of FSH, our research interest has centred on both intra- and interovarian factors that modulate the action of gonadotrophins on the follicle.

\section{Intraovarian control of follicle development}

Our hypothesis is that the physiological basis of follicle selection is the differential expression of factors that modulate the action of gonadotrophins on follicular cells, at key points during the process

\footnotetext{
Fig. 2. The effect of withdrawal of FSH support on follicular development with and without replacement with LH. Follicle development was stimulated in two groups of ewes with ovarian autotransplants (treated with a potent GnRH antagonist to suppress endogenous gonadotrophins) by continuous infusion of oFSH-S16 $\left(5 \mu \mathrm{g} \mathrm{h}^{-1}\right)$ for 3 days. The first group of ewes (a) $(n=5)$ received no LH whilst the second group (b) $(n=3)$ received pulses of LH every $4 \mathrm{~h}(2.5 \mu \mathrm{g}$ oLH-S26) during the initial 3 days of FSH treatment and an increasing regimen of LH to a maximum of 1 pulse $\mathrm{h}^{-1}$ following the end of the FSH infusion. Sixty hours after the end of the FSH infusion both groups of ewes received an ovulatory dose of LH (150 $\mathrm{g} \mathrm{h} \mathrm{h}^{-\mathrm{I}}$ for $8 \mathrm{~h}$; represented by hatched bar). The upper pane] in both (a) and (b) shows the peripheral FSH $(0)$ and LH (•) profiles imposed by the gonadotrophin regimens, whereas the main body of the lower panel in both (a) and (b) shows endogenous oestradiol secretion rate and the inserts show responses to test pulses (arrowheads) of LH (2.5 $\mu \mathrm{g}$ oLH-S26). Withdrawal of FSH support without LH in Group 1 led to regression of the ovulatory follicle as shown by the fall in the oestrogen response to test LH pulses. None of the Group 1 ewes ovulated in response to the LH surge. In contrast, in Group 2, ovulatory follicles were able to transfer their gonadotrophic requirement from FSH to LH and these follicles continued to develop as shown by the oestradiol response to the LH challenge and ovulated in response to the LH surge. (Reproduced from Campbell et al., 1993a.)
} 


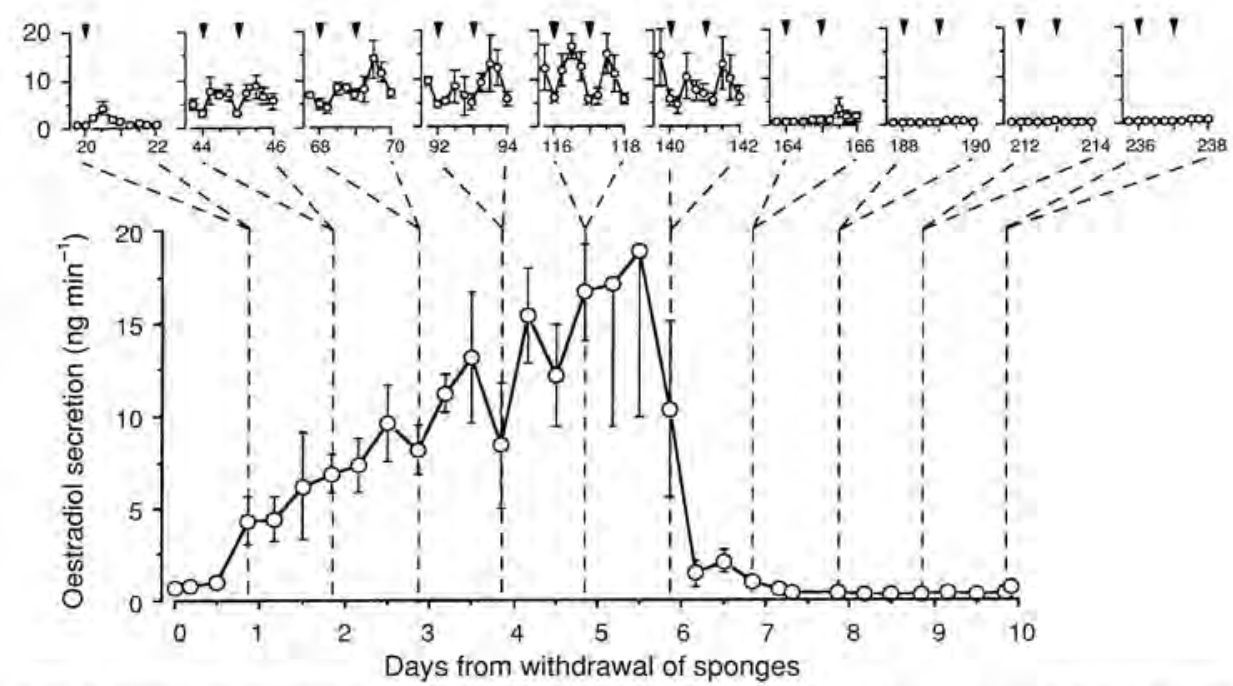

Fig. 3. Ewes with autotransplanted ovaries were treated with a potent GnRH antagonist at the time of luteal regression to depress endogenous gonadotrophins. Endogenous LH was replaced by a stimulatory regimen of low amplitude LH pulses $(2.5 \mu \mathrm{g}$ oLH-S26), designed to mimic the normal follicular phase, building to a maximum frequency of 1 pulse $h^{-}$. This pulsatile regimen of LH was continued for 6 days, 3 days longer than the normal follicular phase, and then discontinued, except for two test pulses each day $(2.5 \mu \mathrm{g}$ oLH-S26). The main body of the figure shows oestradiol secretion rate determined from samples collected every $4 \mathrm{~h}$, and the inserts show responses to injections of LH (arrowheads). As in the normal follicular phase, the ovulatory follicle developed under the influence of high frequency LH pulses, as shown by both the steady increase in endogenous oestradiol secretion and the amplitude of pulsatile response to LH challenge. Owing tó the presence of the GnRH antagonist, this oestradiol cannot induce a preovulatory LH surge and the ovulatory follicle continues to develop until LH is withdrawn on day 6 . Within $24 \mathrm{~h}$ of stopping the pulsatile LH regimen the ovulatory follicle lost the ability to respond to test pulses of LH and began to regress. (Reproduced from Dobson et al., 1994.)

of follicle development. On the basis of numerous studies in vitro, many of them in rodents (Hsueh et al, 1989), these factors could enhance or attenuate the action of gonadotrophins in one of two ways. First, by increased or premature production of factors that stimulate follicular cell differentiation to enhance steroid and inhibin production and induce hormone receptors. Examples of such factors include the insulin-like growth factors (IGF; Adashi et al., 1985), transforming growth factor $\beta$ (TGF- $\beta$ : Adashi and Resnick, 1986) and activin (Ying, 1988). The second way is by increased or retarded production of a factor that stimulates cell division and inhibits differentiation. Examples of such factors include transforming growth factor $\alpha$ (TGF- $\alpha$; Adashi and Resnick, I986), epidermal growth factor (EGF; May and Schomberg, 1989), fibroblastic growth factor (FGF; Baird ef al., 1986) and the insulin-like growth factors binding proteins (IGFBP; Riccarelli et al., 1992). The aim of our research was to extend these findings to sheep and cattle using both in vivo and in vitro models.

In vivo evidence. Sheep studies in vivo made use of the ovarian autotransplant model which is uniquely suited to the study of the effects of putative modulators of ovarian function, as substances can be directly infused into the ovarian artery exposing the ovary to high local concentrations, but low peripheral concentrations. The morphological and endocrine responses to such exposure can then be determined using ultrasound to estimate the ovarian follicle population, whilst simultaneously collecting ovarian venous blood for estimation of the rate of ovarian hormone secretion. Using this model, we have accumulated evidence to show that EGF (Murray et al, 1992), TGF- $\alpha$ (Campbell et al, 1994b), basic FGF (bFGF; B. K. Campbell unpublished observations), inhibin and steroid-free bovine follicular fluid (Campbell et al., 1992) inhibit ovarian function in vivo. Exposure of the ovary to high concentrations of 
(a)
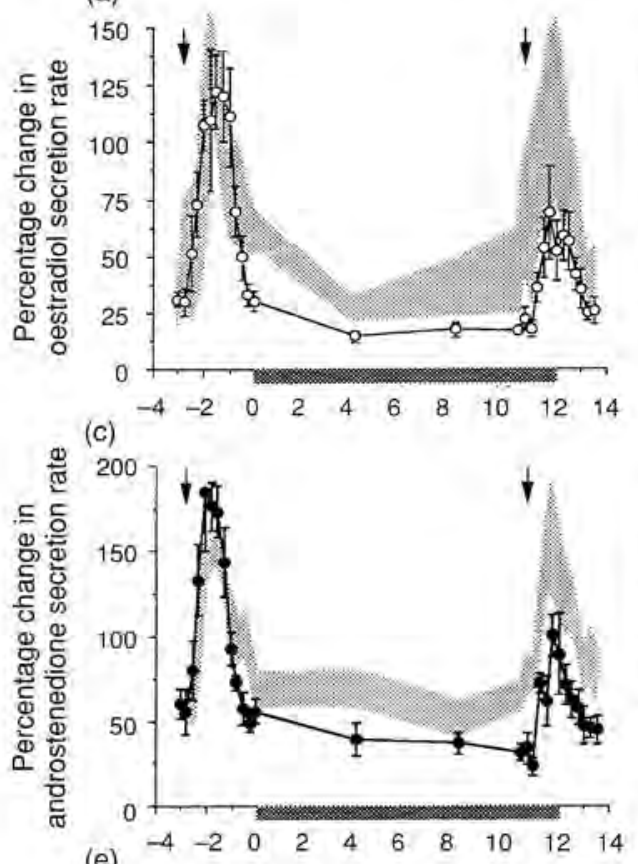

(e)

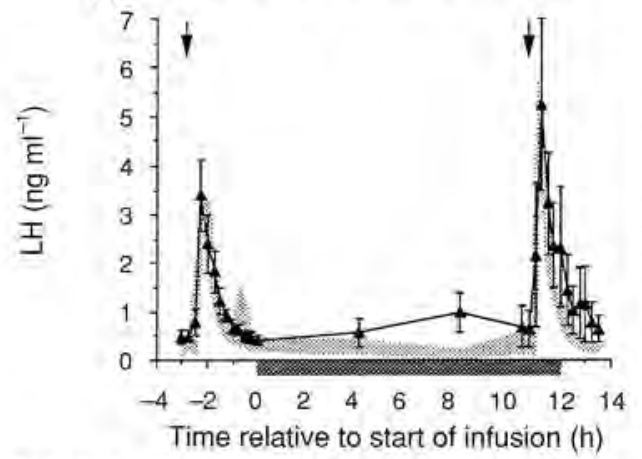

(b)
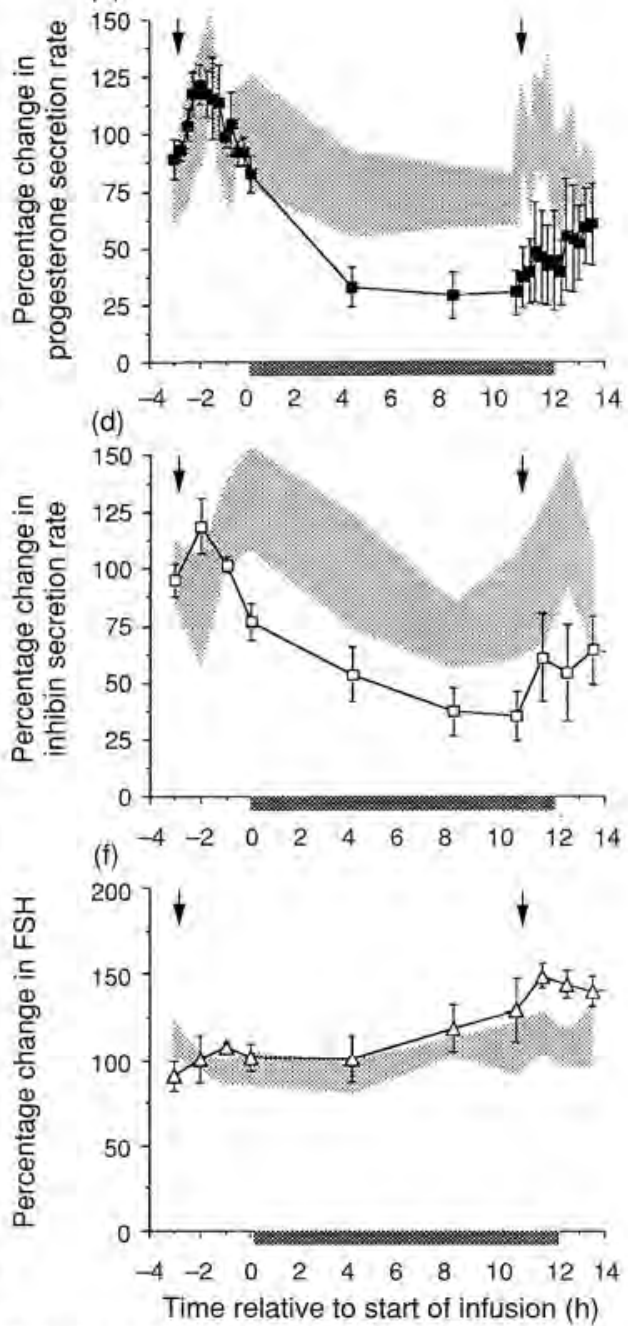

Fig. 4. Effect of infusion of $5 \mu \mathrm{g}$ transforming growth factor $\alpha \mathrm{h}^{-1}$ for $12 \mathrm{~h}$ (horizontal hatched bar) $(n=6)$ on day 10 of the luteal phase on mean \pm SEM (a-d) ovarian hormone secretion and jugular venous (e) $\mathrm{LH}$ and (f) FSH concentrations. All ewes received $150 \mathrm{ng}$ gonadotrophin releasing hormone i.m. (arrows) before and towards the end of the infusion. With the exception of $\mathrm{LH}_{\text {, values have been }}$ expressed as a percentage relative to preinfusion values. The lightly shaded area indicates mean \pm SEM concentrations in placebo-treated ewes $(n=5)$. (Reproduced from Campbell et al., 1994b.)

TGF- $\alpha$ in vivo resulted in the acute inhibition in the secretion of oestradiol and inhibin, synthesized by granulosa cells, androstenedione, synthesized by theca cells, and progesterone, synthesized during the luteal phase principally by luteal cells (Fig. 4). The inhibition of ovarian steroid and inhibin secretion was associated with induction of atresia in the large follicle population suggesting that TGF- $\alpha$ is not simply a developmental paracrine factor but that its selective expression and production play a central role in the mechanism of selection of the ovulatory follicle.

In contrast to the large number of factors shown to inhibit ovarian function in vivo, only IGF-I has been shown to stimulate ovarian hormone secretion (Fig. 5). Infusion of an IGF-I analogue, which has enhanced bioactivity due to decreased affinity for IGFBPs, resulted in an acute and prolonged stimulation in ovarian steroid secretion (Campbell et al., 1993b), indicating that IGF-I can act in vivo to 


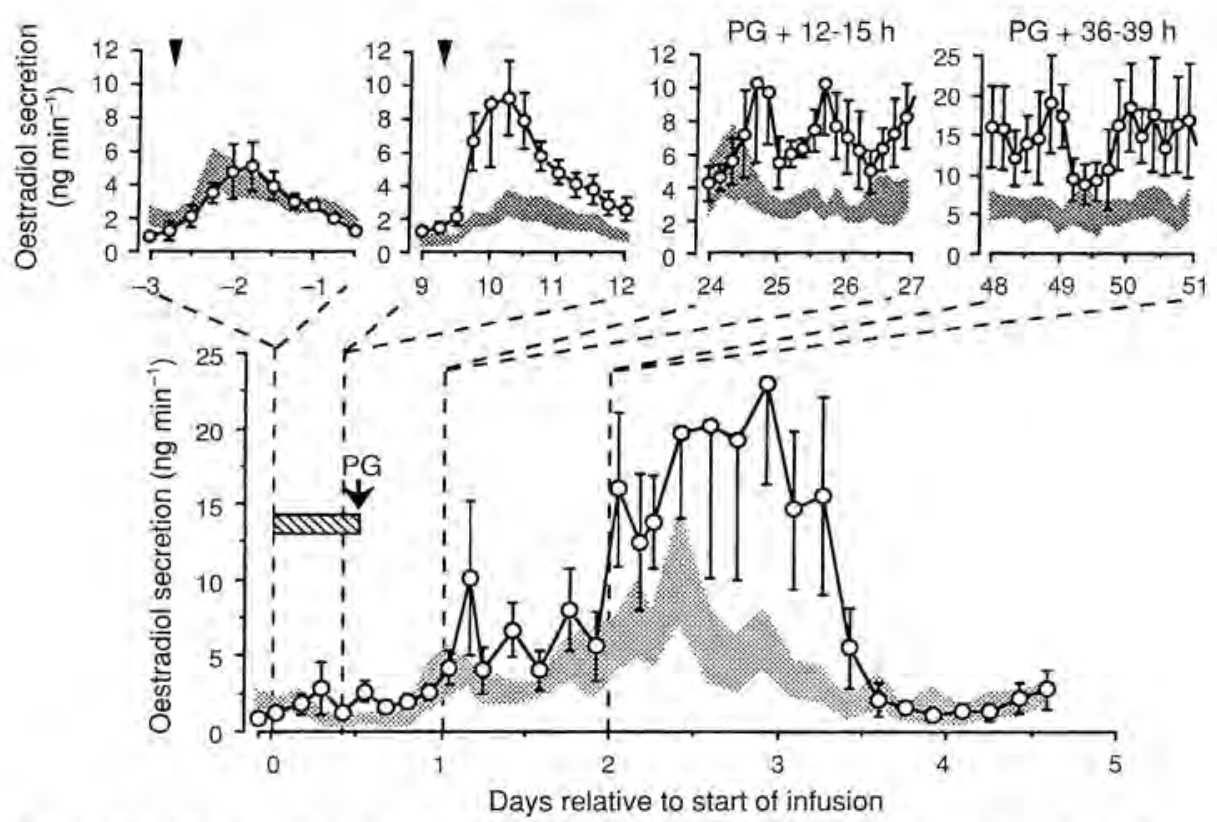

Fig. 5. Effect of infusion of $10 \mu \mathrm{g} \mathrm{h}^{-1}$ for $12 \mathrm{~h}$ (hatched horizontal bar) of an IGF-I analogue (Long R3 IGF-I) $(n=5)$ on day 10 of the luteal phase on ovarian oestradiol secretion (mean \pm SEM) over the period of the infusion and during the subsequent $\mathrm{PGF}_{2 a}$-induced (PG arrows) follicular phase, The main body of the figure shows endogenous oestradiol secretion rate, whereas the inserts show pulsatile responses to $\mathrm{GnRH}$ (arrowheads, $150 \mathrm{ng}$. i.v, ) or endogenous (follicular phase) LH pulses. The lightly shaded area indicates mean \pm SEM values in placebo-treated ewes $(n=5)$. (Reproduced from Campbell ef al., 1993b.)

enhance hormone production by ovulatory gonadotrophin-dependent follicles. These stimulatory effects of IGF-I may help explain the stimulation of follicle development observed in sheep (Gong et al., 1994) and cattle (Gong et al, 1993a) following administration of recombinant bovine somatotrophin (BST). As shown in Fig. 6, administration of BST on day 7 of the luteal phase results in a twofold stimulation of the number of gonadotrophin-responsive follicles ( $<5 \mathrm{~mm}$ in diameter). These induced follicles appear to be fully functional since BST treatment followed by a superovulatory gonadotrophin regimen results in an enhancement in the magnitude and repeatability of the superovulatory response (Gong et al., 1993b). Recent investigations have shown that these folliculogenic responses to BST treatment are still observed in animals in which endogenous gonadotrophins are suppressed by treatment with a $\mathrm{GnRH}$ agonist (J. G. Gong, unpublished), indicating that this effect is due to either a direct action of BST or BST-stimulated insulin or IGF, on the ovary. Our inability to demonstrate direct effects of growth hormone or insulin alone on gonadotrophin stimulated ovarian hormone secretion in sheep (Downing et al., 1993a, b) indicates that stimulation of circulating or intraovarian IGF-I or IGF-II concentrations is the most likely mechanism for the action of BST on follicle development.

In summary, we have used the ovarian autotransplant model to provide evidence that a number of different factors can have major inhibitory and stimulatory actions on ovarian function in vivo, thus supporting the hypothesis that the basis of follicle selection is the modulation of the action of gonadotrophins by locally produced factors. However, this model cannot provide insights into the mechanisms of action of these factors at a cellular and molecular level. Recent research, therefore, has also focused on the development and application of physiological culture systems for sheep and cattle follicular cells.

In vitro evidence. It appears self-evident that to be able to make physiologically relevant inferences from cultured cells it is imperative to have a culture system in which the cells secrete the same hormones 


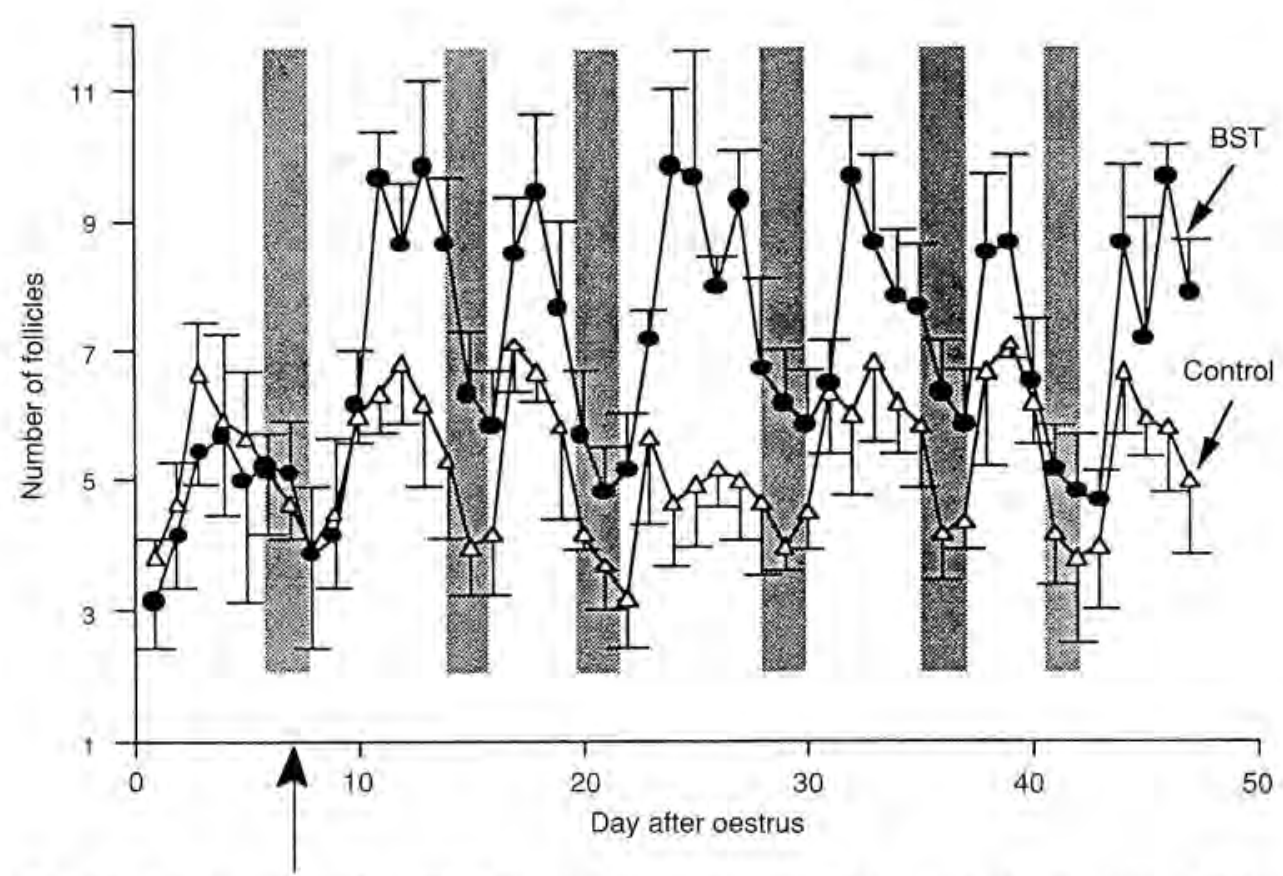

Fig. 6. Mean ( \pm SEM) number of follicles $<5 \mathrm{~mm}$ in diameter before and after the start of daily injections of either bovine somatotrophin (BST: $; n=6$ ) or vehicle $(\Delta ; n=6)$. All animals with either two or three waves of dominant follicles have been included in the figure. Heifers were injected daily with $25 \mathrm{mg}$ BST or vehicle from day 7 of the oestrous cycle for approximately two oestrous cycles. The arrows indicate start of daily BST or vehicle injection. The period (mean day $\pm \mathrm{SEM}, n=12$ as there was no difference in this parameter between the two groups) when the dominant follicles reached their maximum size is shown by the hatched boxes. (Reproduced from Gong et al., 1993a.)

and exhibit the same hormonal responses as cells in vivo. The development of such a culture system for granulosa and theca cells from both sheep and cattle has proved difficult because these cells undergo rapid luteinization when placed in culture. This differentiation process is characterized by decreased synthesis of oestradiol and inhibin by granulosa cells and of the synthesis of androgen by theca cells, with a concomitant marked increase in progesterone synthesis. Furthermore, the proliferative and differentiative responses of cultured granulosa and theca cells to FSH or LH are either lost or can only be induced using supraphysiological hormone concentrations. Indeed many of the reports of hormone production for cultured sheep and cattle follicular cells include only progesterone secretion. Alternatively, results are presented for the main follicular hormones from relatively short-term cultures in which the cells are undergoing early luteinization and retain the ability to synthesize some of these hormones. Results from such studies can be misleading because the hormonal responses to various treatments may simply reflect a change in the rate of luteinization.

We have successfully developed a serum-free cell culture system for both ovine (Campbell et al., 1994a) and bovine (Gutierrez et al., 1994) granulosa cells. Both FSH-responsive induction of aromatase activity by undifferentiated granulosa cells from gonadotrophin-responsive follicles and the maintenance of aromatase activity by differentiated granulosa cells from gonadotrophin-dependent and ovulatory follicles have been achieved using these systems (Fig. 7). Interestingly, the follicle size classes in which the endogenous aromatase activity of the granulosa cells was negligible was similar in sheep and cattle, indicating similar stages of granulosa cell differentiation in relation to follicle diameter, despite the fact that gonadotrophin-dependent and ovulatory follicles are much larger in cattle than in sheep. Despite this similarity in stage of development relative to follicular diameter, it is clear that the capacity of cow granulosa cells to synthesize oestradiol is ten times higher than that of sheep granulosa cells and that 

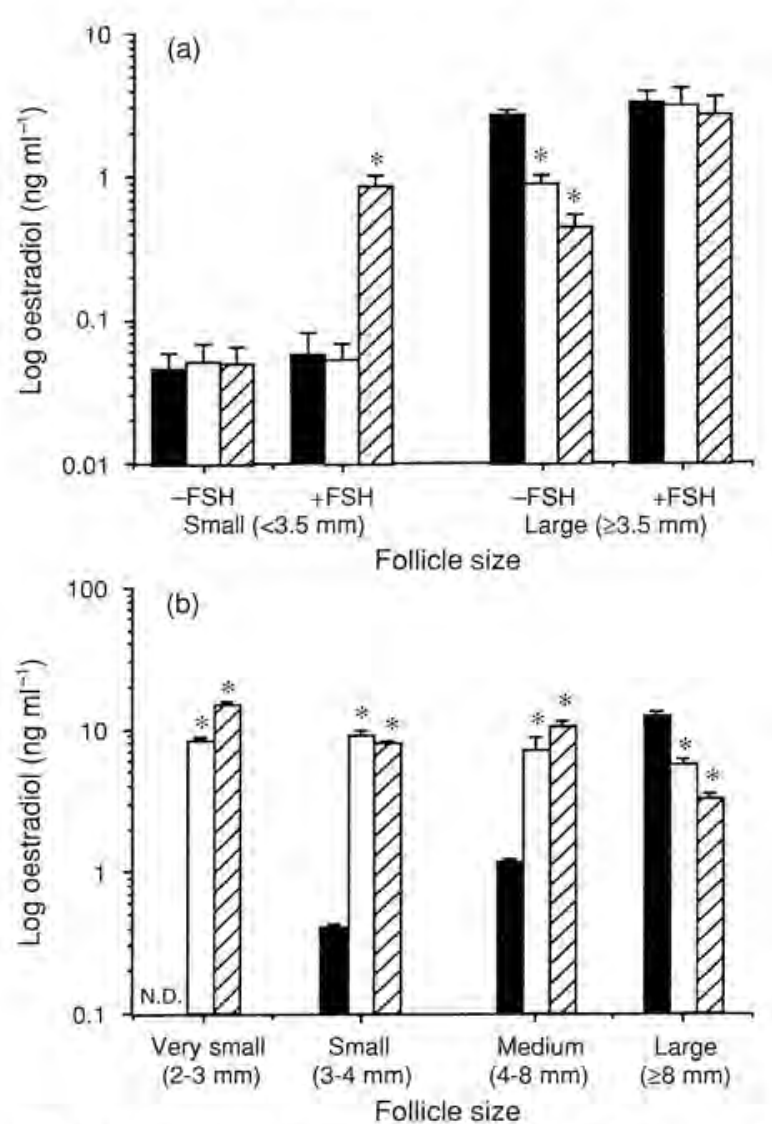

Fig. 7. The changes in oestradiol synthesis, with time, by granulosa cells isolated from (a) sheep and (b) cattle follicles of different sizes cultured under identical serum-free condifions in the presence of $10 \mathrm{ng}$ insulin $\mathrm{ml}^{-1}$ and $10 \mathrm{ng}$ IGF-1

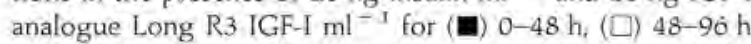
and (Z2) $96-144 \mathrm{~h}$. Data from sheep shows the effect of the presence or absence of $10 \mathrm{ng}$ oFSH-SI $6 \mathrm{ml}^{-1}$, whilst data from the cow is derived from cells stimulated with I ng USDA-bFSH-12 $\mathrm{ml}^{-1}$. Oestradiol production by bovine granulosa cells from very small follicles from $0-48 \mathrm{~h}$ of culture was not detectable (N.D.). (*Significantly different from $0-48$ h culture period, $P<0.05$; ANOVA.)

aromatase activity can be induced more quickly in cow cells than in sheep granulosa cells (Fig. 7). The reason for these differences is unclear.

Sheep and cattle granulosa cells cultured under serum-free conditions exhibit dose-dependent proliferative and oestrogenic responses to physiological doses of FSH. In sheep, there are marked differences in the responsiveness of cells from small ( $<3.5 \mathrm{~mm}$ diameter) and large follicles to FSH (Fig. 8). Cells from small follicles exhibit maximum proliferative and oestrogenic responses at doses between 0.5 and $10 \mathrm{ng}$ oFSH-SI6 $\mathrm{ml}^{-1}$, respectively, and higher doses of FSH have no inhibitory effects. In contrast, FSH stimulates oestradiol synthesis by the differentiated cells from large follicles without

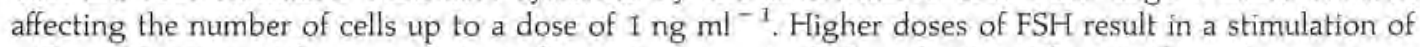
cell proliferation, with a concomitant depression in oestradiol production. Thus, in this culture system, FSH can stimulate undifferentiated granulosa cells to simultaneously divide and synthesize oestradiol, whereas these responses are inversely related in differentiated granulosa cells. These responses to FSH 

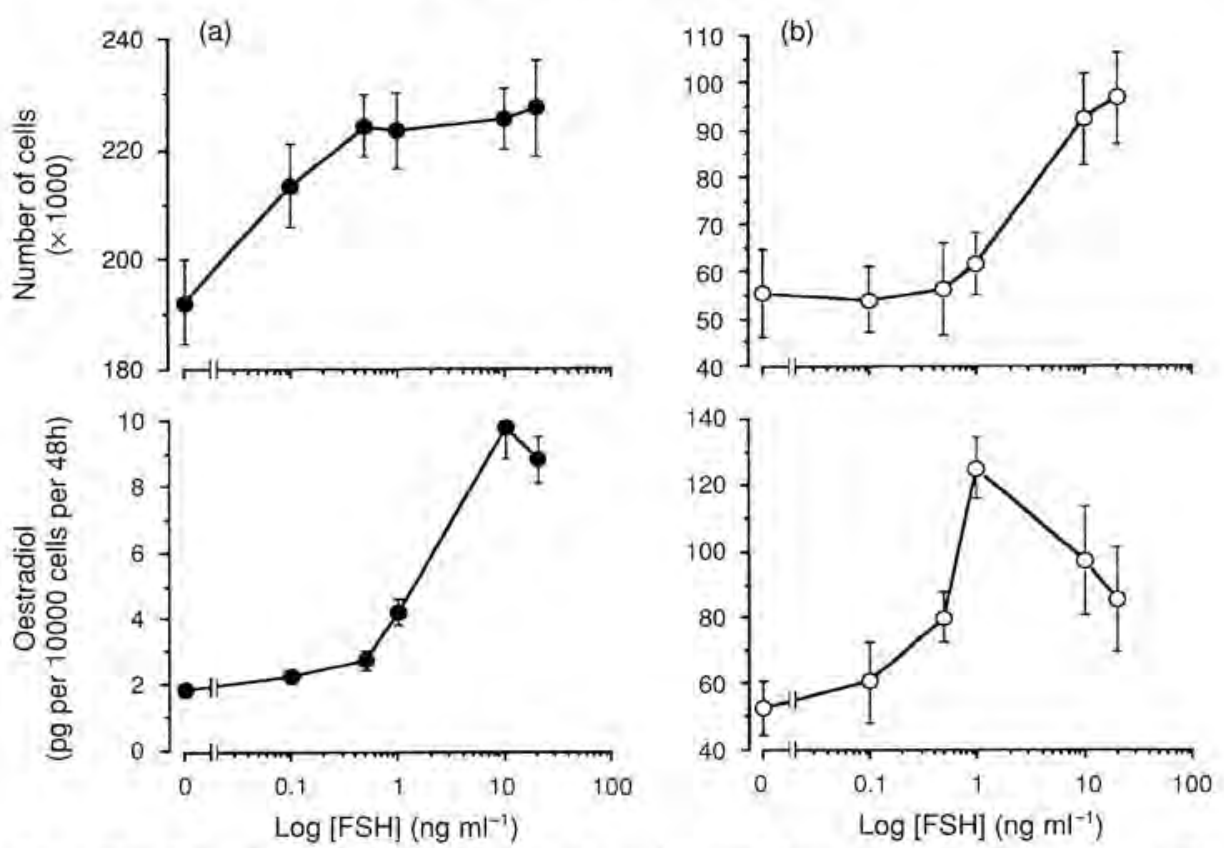

Fig. 8 . The effect of oFSH-S16 on number of cells and oestradiol synthesis by sheep granulosa cells isolated from (a) small $(<3.5 \mathrm{~mm})$ and (b) large $(\geq 3.5 \mathrm{~mm}$ ) follicles after 6 days of culture under serum-free conditions in the presence of $10 \mathrm{ng}$ insulin $\mathrm{ml}^{-1}$ and $10 \mathrm{ng}$ IGF-I analogue Long R3 IGF-I ml ${ }^{-1}$. (Reproduced from Campbell et al., 1994a.)

in vitro parallel closely the changes observed in granulosa cells in vivo during FSH-induced follicle development. In addition, these stimulatory effects of FSH on oestradiol synthesis by granulosa cells can be reversed by a specific aromatase inhibitor (B. K. Campbell, unpublished). Further evidence of the physiological nature of this granulosa cell culture system comes from observations on two other markers of granulosa cell differentiation. Like oestradiol, the ability of cultured sheep granulosa cells from small follicles to synthesize inhibin increases markedly with time of culture, but unlike oestradiol this increase does not depend on FSH when the results are expressed on a per cell basis (B. K. Campbell, unpublished). This observation supports findings in vivo that ovarian inhibin secretion is not acutely responsive to FSH (Campbell et al., 1991b) and suggests that the increase in ovarian inhibin secretion observed following FSH infusion (Campbell et al., I993a) simply reflects an increase in the number of granulosa cells. A further marker of granulosa cell differentiation is the development of LH receptors. Recent studies have shown that cultured granulosa cells from small sheep follicles do develop the ability to respond to LH in parallel with an ability to secrete oestradiol and that this responsiveness depends on FSH (B. K. Campbell, unpublished). Furthermore, while low doses of LH stimulated oestradiol synthesis, higher doses were inhibitory, which again closely parallels responses observed in vivo (Baird and McNeilly, 1981). From the evidence presented above, we conclude that the culture system for sheep and cattle granulosa cells that we have developed is physiological and that physiologically relevant inferences can be drawn from it. The ability to stimulate undifferentiated granulosa cells from gonadotrophinresponsive follicles, to secrete oestradiol and inhibin and develop LH receptors in vitro provides an ideal model to study the cascade of events that control granulosa cell differentiation and ultimately follicle selection. Initial studies using the technique of differentiational display (Liang and Pordee, 1992) to identify key changes in gene expression during this process indicate that FSH-responsive changes may be in the level of expression rather than in absence or presence of particular RNA species (M. Clinton, D. McBride, R. Webb and B. Campbell, unpublished). However, the results of this analysis provide further strong evidence that granulosa cells stimulated to differentiate in vitro are not undergoing terminal differentiation into luteal cells. 

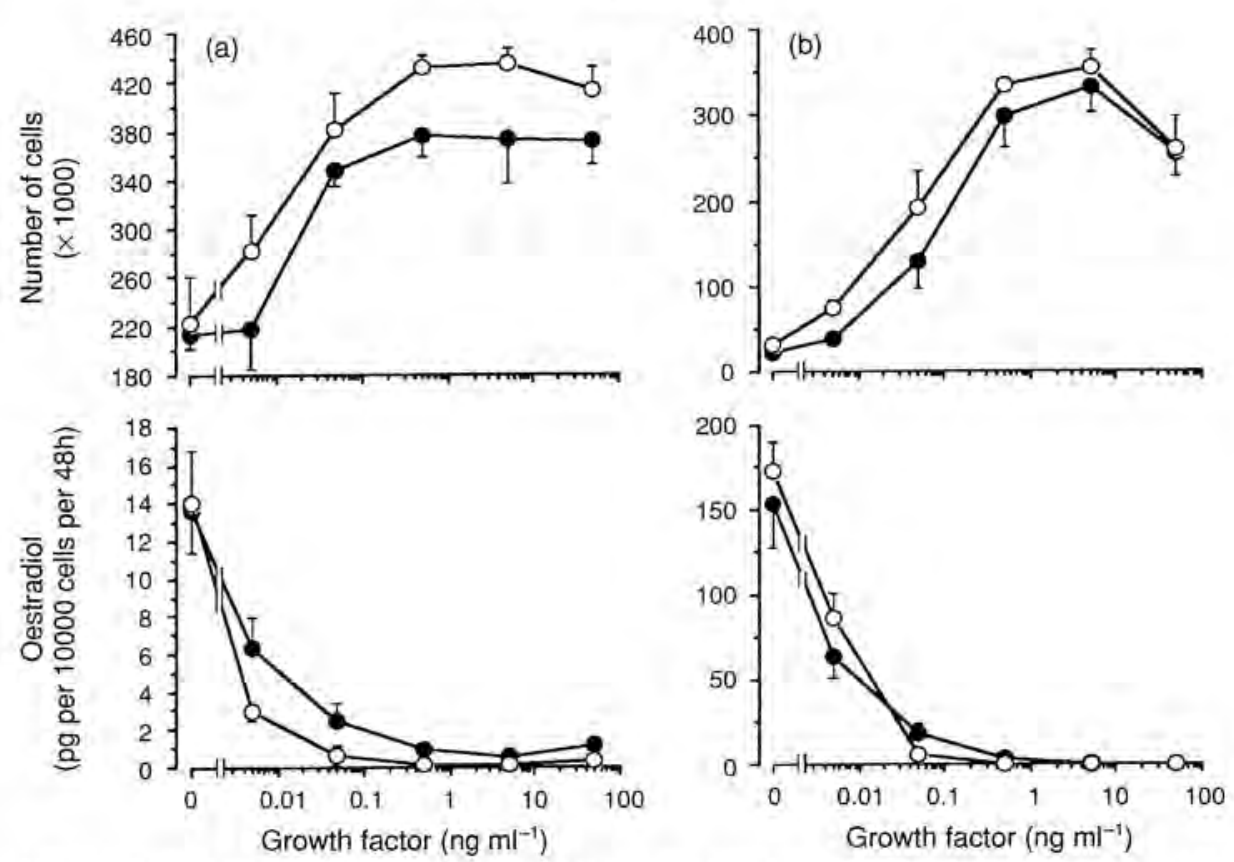

Fig. 9. Effect of epidermal growth factor (EGF) (O) and transforming growth factor $\alpha$ (TGF- $\alpha$ ) (-) on number of cells and the oestradiol synthesis by sheep granulosa cells isolated from small $(<3.5 \mathrm{~mm})$ and large $(\geq 3.5 \mathrm{~mm})$ follicles after 6 days of culture under serum-free conditions in the presence of $10 \mathrm{ng}$ insulin $\mathrm{ml}^{-1}, 10 \mathrm{ng}$ IGF-1 analogue Long R3. IGF-I ml ${ }^{-1}$ and $10 \mathrm{ng}$ oFSH-Si6 $\mathrm{ml}^{-1}$. (Reproduced from Campbell et al., 1994a.)

Using this granulosa cell model system, we confirmed and extended the results of many of our studies in vivo and two examples will be given here. Both EGF and TGF- $\alpha$ stimulate marked increases in proliferation of granulosa cells from small and large follicles and a concomitant inhibition of oestradiol and inhibin synthesis (Fig. 9). The biopotency of both these growth factors was similar with granulosa cells from both size classes exhibiting maximal responses at doses of $500 \mathrm{pg} \mathrm{ml}^{-1}$. In contrast to the proliferative growth factors, insulin (at supraphysiological doses), IGF-I and IGF-II can all stimulate granulosa cell proliferation in conjunction with increasing oestradiol and inhibin synthesis (on a per cell basis). Although the effects of insulin at supraphysiological doses $\left(5 \mu \mathrm{g} \mathrm{ml}{ }^{-1}\right.$; Fig. 10) are probably mediated via the type I IGF receptor (Adashi et al., 1985), we have shown that both IGF-I and insulin interact at physiological concentrations to influence both cellular proliferation and hormone production (Fig. 10), Of the IGFs, IGF-I appears to be the more important, as it is about five times more potent in stimulating cellular proliferation and hormone production than is IGF-II (B. K. Campbell and R. Webb, unpublished).

\section{Follicular Dominance in Monovular Species}

When considering locally mediated mechanisms of follicle selection in monovular species, there must be a mechanism whereby the ovulatory follicle can inhibit the development of follicular cohorts in both ovaries. Although the evidence presented above is consistent with a mechanism mediated via modulation of peripheral FSH concentrations by the level of oestradiol and inhibin secretion by the ovulatory follicle, there is strong evidence for an alternative mechanism that relies on secretion of factors by the ovulatory follicle that directly inhibits development of subordinate follicles.

Some of the most compelling evidence for the existence of such a mechanism in large domestic ruminants was the demonstration that inhibin-free ovine or bovine follicular fluid could acutely inhibit 

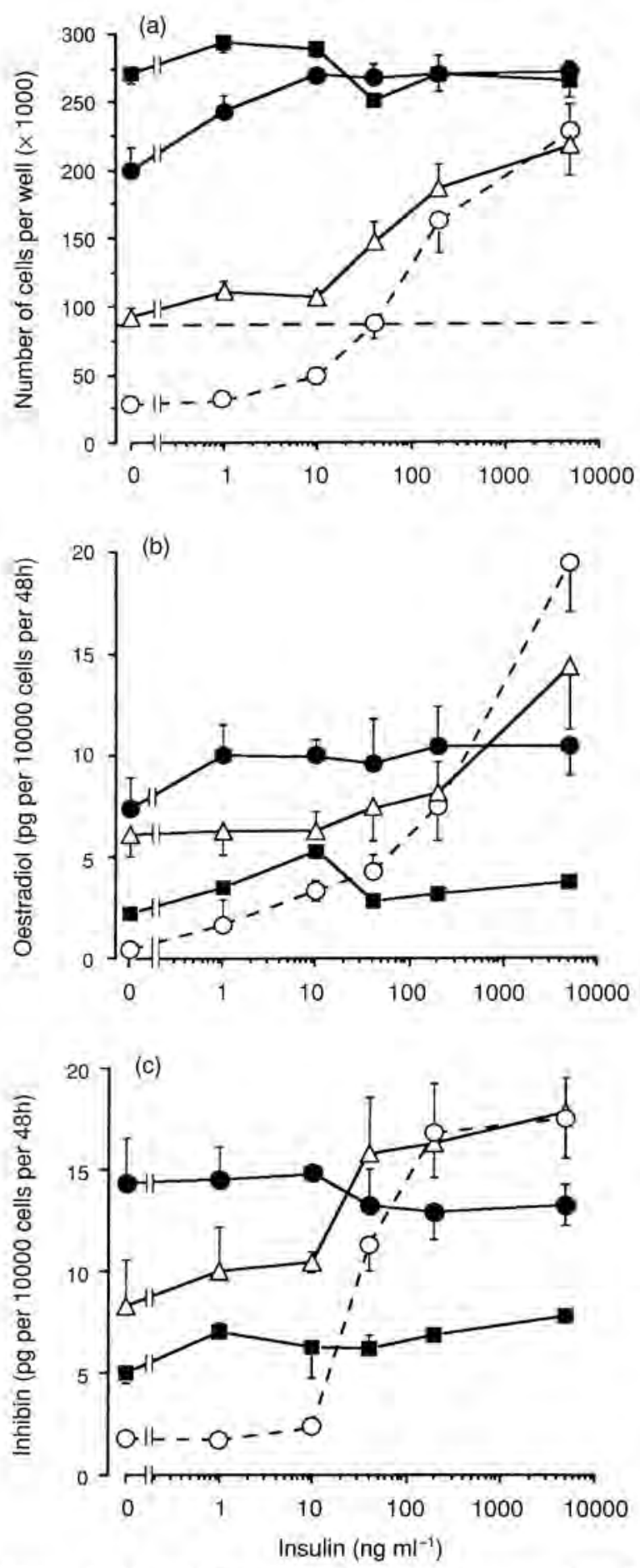

Fig. 10. The interaction between insulin and IGF-I (in the form of the arialogue Long R3 IGF-I) in the stimulation of (a) number of cells and (b) oestradiol and (c) inhibin synthesis by sheep granulosa cells isolated from small $(<3,5 \mathrm{~mm})$ follicles after 6 days of culture under serum-free conditions in the presence of $10 \mathrm{ng}$ oFSH-SIo ml ${ }^{-1}$

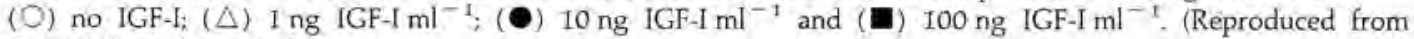
Campbell et al., 1994a.) 
ovarian hormone secretion and follicle development in sheep (Campbell et al., 1991c) and cattle (Law et al, 1992), without significantly changing peripheral FSH concentrations. This effect was confirmed when it was demonstrated that direct ovarian infusion of bovine follicular fluid could inhibit ovarian function without any change in FSH concentrations (Campbell et al, 1992). Furthermore, recent studies have shown that partially purified preparations of bovine follicular fluid containing negligible quantities of inhibin can delay oestrus in cyclic ewes (O'Shea et al, 1993) and inhibit the aromatase activity of cultured granulosa cells (B. K. Campbell, unpublished). Although the identity of the factor responsible for this activity remains unknown, both IGF binding protein-3 (Shimasaki et al., 1990) and the $\alpha$-chain of inhibin (Schneyer et al., 1991) have been isolated from follicular fluid and characterized on their respective ability to inhibit aromatase and FSH receptor binding in vitro. Although evidence that such factors are actually secreted into the peripheral circulation is still lacking, there is some circumstantial evidence for their existence. For example, it has been noted that superovulatory responses are muted in cattle when given in the presence of an ovulatory follicle (Guilbault et al., 1991) and an inverse relationship between the number of subordinate follicles and the presence of the ovulatory follicle has been reported in cattle (Gong et al, 1993a; Fig. 6).

Neither of the mechanisms of dominance discussed above are mutually exclusive and it is possible that both mechanisms could operate to varying degrees in different species. Such a hypothesis could help explain the observation that the degree of dominance is much more marked in cattle than in sheep (Driancourt et al., 1991). Thus in cattle, where the one ovulatory follicle is readily identifiable from cohorts by its size, the ovarian inhibitor mechanism may be more active than in sheep, in which the ovulatory follicle(s) cannot be reliably identified solely on the basis of size (Webb and Gauld, 1985). However, the testing of this hypothesis must await the identification of the factor(s) present in ovine and bovine follicular fluid that can inhibit follicle development.

\section{Conclusion}

From the preceding discussion, it is proposed that antral follicle development and selection in sheep and cattle is a complex multifactorial process with different levels of control. The first level of control lies with the pituitary gonadotrophins which are essential for the development of an ovulatory follicle and it is through the modulation of the action of gonadotrophins that subsequent levels of control act. The second level of control is the production of factors by the ovulatory follicle that actively suppress the development of follicular cohorts through modulation of gonadotrophic-dependent mechanisms. The final level of control is the intrafollicular cascade of events that enhance or attenuate the action of the gonadotrophins in stimulating the growth and differentiation of cells within an ovulatory follicle. In this paper, we have presented evidence to support the existence of all three mechanisms in the control of follicle development and selection in sheep and cattle. The development, for the first time, of a physiological granulosa cell culture system for sheep and cattle provides us with a valuable model to elucidate the mechanism of follicle selection in these two species.

The authors would like to thank G. Baxter, D. McBride, J. A. Downing and B. Gordon for technical assistance in the conduct of the experiments reported in this paper. They also thank J. G. Gong and C. Gutierrez for helpful discussions in the preparation of this manuscript.

\section{References}

Adashi LY and Resnick CL (1986) Antagonistic interactions of transforming growth factors in the regulation of granulosa cell differentiation Endocrinology 119 18791881

Adashi EY, Resnick CE, D'ercole AJ, Svoboda ME and Van Wyk JJ (1985) Insulin-like growth factors as intraovarian regulators of granulosa cell growth and function Endocrine Reviews 6 $400-420$

Baird DT and McNeilly AS (1981) Gonadotrophic control of follicular development and function during the oestrous cycle of the ewe Journal of Reproduction and Fertility Supplement $30119-133$

Baird A, Esch F, Mormede P, Ueno N, Ling N, Bohlen P, Ying S-Y, Wehrenberg WB and Guillemin R (1986) Molecular characterization of fibroblast growth factor: distribution and biological activities in various tissues Recent Progress in Hormone Research 42 143-203

Cahill LP and Mauleon P (1981) A study of the population of primordial and small follicles in the sheep Journal of Reproduction and Fertility 61 201-206 
Campbell BK, Mann GE, McNeilly AS and Baird DT (1990) The pattern of ovarian inhibin, estradiol and androstenedione secretion during the estrous cycle in the ewe Endocrinology $127 \quad 227-235$

Campbell BK, Scaramuzzi RJ, Evans G and Downing JA (1991a) Increased ovulation rate in androstenedione-immune ewes is not due to elevated plasma concentrations of FSH Jourual of Reproduction and Ferlility 91 655-666

Campbell BK, McNeilly AS, Picton HM and Baird DT (1991b) The effect of FSH on inhibin secretion in anoestrous ewes Journal of Reproduction and Fertility 91 501-509

Campbell BK, Picton HM, Mann GM, McNeilly AS and Baird DT (1991c) The effect of steroid- and inhibin-free ovine follicular fluid on ovarian follicle populations and ovarian hormone secretion Joumal of Reproduction and Fertility 93 $81-96$

Campbell BK, Tsonis CG, Gordon BM and Scaramuzzi RJ (1992) Ovarian arterial infusion of recombinant human inhibin and bovine follicular fluid inhibits ovarian oestradiol secretion Journal of Reproduction and Fertility Abstract Series 9 Abstract 20

Campbell BK, Gordon BM. Dobson H and Scaramuzzi RJ (1993a) The relative role of $\mathrm{LH}$ and $\mathrm{FSH}$ in the growth and maintenance of preovulatory follicles Journal of Reproduction and Fertility Abstract Serics 11 Abstract 21

Campbell BK, Gordon BM, Dobson H and Scaramuzzi RJ (1993b) Insulin-like growth factor can stimulate oestradiol production both in vivo and in vitro lournal of Reproduction and Ferrility Abstract Series 12 Abstract 21

Campbell BK, McBride D and Webb R (1994a) Interaction between insulin and IGF-I in the stimulation of proliferation and oestradiol production by cultured ovine granulosa cells from small follides Journal of Reproduction and Fertility Abstract Series 13 Abstract 19

Campbell BK, Gordon BM and Scaramuzzi RJ (1994b) The effect of ovarian arterial infusion of transforming growth factor $u$ on ovarian follicle populations and ovarian hormone secretion in ewes with an aulotransplanted ovary Joumal of Endoctinology $143 \quad 13-24$

Dobson H, Campbell BK, Gordon B and Scaramuzzi RJ (1994) Endocrine activity of persistent ovarian follicles in the sheep Journal of Reproduction and Fertility Abstract Series 13 Abstract 61

Downing JA, Scaramuzzi RJ and Joss J (1993a) The direct effect of insulin on ovarian steroid secretion in ewes with an autotransplanted ovary Proceedings of the Australian Society of Reproduclive Biology Abstract 83

Downing JA, Scaramuzzi RJ and Joss J (1993b) The direct effect of growth hormone on ovarian steroid secretion in ewes with an autotransplanted ovary Proceedings of the Australian Society of Reproductive Biology Abstract 84

Driancourt MA, Philipon P, Locatelli A, Jacques E and Webb R (1988) Are differences in FSH concentration involved in the control of ovulation rate in Romanov and lle-de-France ewes? Joumal of Reproduction and Fertility 83 509-516

Driancourt MA, Webb R and Fry RC (1991) Does follicular dominance occur in ewes Joumal of Reproduction and Fertility $9363-70$

Findlay JK, Clarke IJ, Luck MR, Rodgers RJ, Shukovski L, Robertson DM, Klein R, Murray JF, Scaramuzzi RJ, Bindon BM, O'Shea T, Tsonis CG and Forage RG (1990) Peripheral and intragonadal actions of inhibin-related peptides Journal of Reproduction and Fertility Supplement 43 139-150

Glencross RG, Bleach EC, McLeod BJ, Beard AJ and Knight PG (1992) Effect of active immunization of heifers against inhibin on plasma FSH concentrations ovarian follide development and oyulation rate Joumal of Endocrinology $1341 \tau-18$

Gong JG, Bramley TA and Webb R (1993a) The effect of recombinant bovine somatotrophin on ovarian follicular growth and development in heiters Joumal of Reproduction and Fertility $97 \quad 247-254$

Gong JG, Bramley TA, Wilmut I and Webb R (1993b) The effect of recombinant bovine somatotrophin on the superovulatory response to pregnant mare serum gonadotrophin in heifers Biology of Reproduction 48 1141-1149

Gong JG, Campbell BK, McBride D and Webb R (1994) The effect of recombinant bovine somatotrophin $(\mathrm{rGH})$ on ovarian follicular populations in mature ewes Joumal of Reproduction and Fertility Abstract Sertes 13 Abstract 22

Guilbault LA, Grasso F, Lussier JG, Rouillier P and Matton P (1991) Decreased superovulatory responses in heifers superovulated in the presence of the dominant follicle Joumal of Reproduction and Fertility $91 \quad 81-89$

Gutierrez CG, Campbell BK, Gong JG and Webb R (1994) An improved long term culture system that maintains aromatase actiyity in bovine granulosa cells Joumal of Reproduction and Fertility Abstract Series 13 Abstract 20

Hsueh AJW, Bicsak TA, Jia X-C, Dahl KD, Fauser BCJM, Galway AB, Czekala N, Pavlou SN, Papkoff H, Keene J and Boime I (1989) Granulosa cells as hormone targets: the role of biologically açive follicle-stimulating hormone in reproduction Recent Progress in Hormone Research 45209 277

Ireland JJ and Roche JF (1983) Development of non-ovulatory antral follicles in heifers: changes in steroids in follicular fluid and receptors for gonadotrophins Endocrinology 112 $150-156$

Lahlou-Kassi A, Schams D and Glatzel P (1984) Plasma gonadotrophin concentrations during the oestrous cycle and after ovariectomy in two breeds of sheep with low and high fecundity Jounal of Reproduction and Fertility 70 $165-173$

Law AS, Baxter G, Logue DN, O'Shea T and Webb R (1992) Evidence for the action of bovine follicular fluid factor(s) other than inhibin and suppressing development and delaying oestrus in heifers Journal of Reproduction and Fertility 96 $603-616$

Liang P and Pordee AB (1992) Differential display of eukaryotic messenger RNA by means of the polymerase chain reaction Science 257 967-971

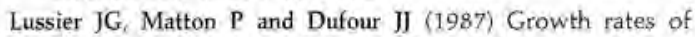
follicles in the ovary of the cow Joumal of Reproduction and Fertility 81 301-307

McNatty KP, Hudson N. Gibb M, Ball K. Henderson KM, Heath DA, Lun S and Kieboom LE (1985) FSH influences follicle viability, oestradiol biosynthesis and ovulation rate in Romney ewes Joumal of Reproduction and Fertility 75 I2I 1.31

McNatty KP, Hudson N, Henderson KM, Gibb M, Morrison L, Ball $K$ and Smith P (1987) Differences in gonadotrophin concentrations and pituitary responsiveness to GnRH between Booroola ewes which were homozygous (FF), heterozygous $(\mathrm{F}+)$ and non-carriers $(++)$ of a major gene influencing their ovulation rate Journal of Reproduction and Fertility 80 577-588

McNeilly AS, Picton HM, Campbell BK and Baird DT (1991) Gonadotrophic control of follicle growth in the ewe Journal of Reproduction and Fertility Supplement 43 177-186 
May JV and Schomberg DW (1989) The potential relevance of epidermal growth factor and transforming growth factoralpha to ovarian physiology Seminars in Reproduclive Endocrinology 7 1-11

Monniaux D, Chupin D and Saumande J (1983) Superovulatory responses of cattle Theriogenology 19 55-81

Murray JF, Downing JA, Evans G, Findlay JK and Scaramuzzi RJ (1992) Epidermal growth factor acts directly on the ovary in vivo to inhibit oestradiol-17B and inhibin secretion and enhance progesterone secretion Journal of Endocrinology $137253-264$

O'Shea T, Baxter G and Webb R (1993) Factors in follicular fluid that delay or hasten oestrus Proceedings of the Australian Society of Reproductive Biology Abstract 57

Picton HM, Tsonis CG and McNeilly AS (1990) FSH causes a time-dependent stimulation of preovulatory follicle growth in the absence of pulsatile LH secretion in ewes chronically treated with gonadotrophin-releasing hormone agonist Joumal of Endocrinology $126 \quad 297-307$

Price CA and Webb R (1989) Ovarian responses to hCG treatment during the oestrous cycle in heifers Journal of Reproduction and Fertility 86 303-308

Rajakoski E (1960) The ovarian follicular system in sexually mature heifers with special reference to seasonal, cyclical and left-right variations Acta Endocrinologica Supplementum $527-68$

Ricarelli E, Hernandez ER, Tedeschi C, Botero LF, Rohan RM, Rosenfeld RG, Albiston AL, Herington AC and Adashi EY (1992) Rat ovarian insulin-like growth factor binding protein-3; a growth hormone dependent theca interstitial cell derived antigonadotropin Endocrinology 130 30923094

Savio JD, Thatcher WW, Badinga $\mathrm{L}_{\mathrm{r}}$ de la Sota RL and Wolfenson D (1993) Regulation of dominant follicle turnover during the oestrous cycle in cows Journal of Reproduction and Fertility 97 197-203

Scaramuzzi RJ (1976) Physiological effects of immunizing sheep against oestradiol-17ß. In Physiological Effects of Immunity against Reproductive Hormones pp 67-90 Eds RG Edwards and $\mathrm{MH}$ Johnson. Cambridge University Press. Cambridge

Scaramuzzi RJ and Radford HM (1983) Factors regulating ovulation rate in the ewe Jounal of Reproduction and Fertility 69 353-36́7
Scaramuzzi RJ, Adams NR, Baird DT, Campbell BK, Downing JA, Findlay JK, Henderson KM, Martin GB, McNatty KP, McNeilly AS and Tsonis CG (1993) A model for follicle selection and the determination of ovulation rate in the ewe Reproduction Fertility and Development 5 459-478

Schneyer AL, Sluss PM, Whitcomb RW, Martin KA, Sprengel R and Cowley WF (1991) Precursors of $\alpha$-inhibin modulate follicle-stimulating hormone receptor binding and biological activity Endocrinology 129 1987-1999

Schrick FN, Surface RA, Pritchard JY, Dailey RA, Townsend EC and Inskeep EK (1993) Ovarian structures during the estrous cycle and early pregnancy in ewes Biology of Reproduction 49 1133-1140

Shimasaki S, Shimonaka M, Ui M, Inouye S, Shibata F and Ling $\mathrm{N}$ (1990) Structural characterization of a follicle-stimulating hormone action inhibitor in porcine ovarian follicular fluid: its identification as the insulin-like growth factor-binding protein Joumal of Biological Chemistry 265 2198-2202

Sirois I and Fortune IE (1988) Ovarian follicular dynamics during the estrous cycle in heifers monitored by real time ultrasound Biology of Reproduction 39 308-317

Turnbull KE, Braden AWH and Mattner PE (1977) The pattern of follicular growth and atresia in the ovine ovary Australian Journal of Biological Stiences 30 229-241

Wallace JM and McNeilly AS (1985) Increase in ovulation rate after treatment of ewes with bovine follicular fluid in the luteal phase of the oestrous cycle Joumal of Reproduction and Fertility 73 505-515

Webb R and England BG (1982) Identification of the ovulatory follicle in the ewe: associated changes in the follicular size. thecal and granulosa cell luteinizing hormone receptors, antral fluid steroidss and circulating hormones during the preovulatory period Endocrinology 110 873-881

Webb R and Gauld IK (1985) Folliculogenesis in sheep: control of ovulation rate. In Genetics of Reproduction in Sheep pp 261-274 Eds RB Land and DW Robinson. Butterworths, London

Ying S-V (1988) Inhibins, activins and follistatins: gonadal proteins modulating the secretion of follicle stimulating hormone Endocrine Reviezos 9 267-293 